\title{
Reuse and Decontamination of N95 Respirators in Dentistry
}

\author{
Vanessa Paiva Reis ${ }^{1}$ \\ ${ }^{1}$ Oral Maxillofacial Surgery and Traumatology Service, Military Police Polyclinic of Cascadura (Policlínica da Polícia Militar de Cascadura), Rio de Janeiro State \\ Military Police, Rio de Janeiro, RJ, Brazil \\ - Conflicts of interest: none declared.
}

\section{Dear Editor,}

$\mathrm{T}$ Three months since the COVID-19 pandemic reached Brazil, many health institutions are facing a shortage of N95/FFP2 (FFP - Filtering Facepiece) or similar respirators. The US Centers for Disease Control and Prevention (CDC) has published a number of strategies for optimizing the supply of these respirators, including the possibility of their reuse without decontamination. ${ }^{1}$ I would like to discuss some of the drawbacks of such practice in the dental care setting.

One of the main concerns about reuse without decontamination is the possibility of contact transmission when the user touches the outside of the respirator. ${ }^{2,3,4}$ Risks associated with reuse could be reduced by placing protective barriers over the respirator, cleaning hands before and after handling the respirator, wearing gloves when adjusting the reused respirator, and leaving it for five days before reuse. ${ }^{2,3,6,7}$ This five-day wait is based on studies of the persistence of SARS-CoV-2 on different surfaces. ${ }^{8}$
Nonetheless, reusing the same respirator without decontamination after leaving it for a period of time fails to take account of the lack of scientific evidence on the survival time of SARS-CoV-2 in respirators, nor does it take into account potential contamination by other pathogens, such as the influenza $A$ virus $(\mathrm{H} 1 \mathrm{~N} 1)=$ (influenza $A$ virus subtype H1N1 (A/H1N1)), which can persist in respirators for up to six days. ${ }^{9}$ Finally, dental care is inherently high-risk because it involves aerosol-generating procedures, after which respirator disposal is recommended. ${ }^{2,3,6}$

Several methods for decontaminating respirators are being tested. Although some studies have shown promising results, there are no regulations in Brazil for this. ${ }^{10}$ The only decontamination method approved by the US Food and Drug Administration (FDA) for emergency and exceptional circumstances is vaporized hydrogen peroxide. ${ }^{11}$ Table 1 presents the decontamination methods, their approval (or not) for emergency use by the FDA, and the manufacturer's evaluation. ${ }^{12}$

Table 1. Methods for the decontamination of N95* respirators, whether approved for emergency use by the Food and Drug Administration (USA), and manufacturer's evaluation.

\begin{tabular}{|c|c|c|}
\hline Decontamination Method & $\begin{array}{l}\text { Authorized or not for } \\
\text { Emergency Use** } \\
\text { (FDA - USA) }\end{array}$ & Manufacturer's Evaluation13 \\
\hline Vaporized hydrogen peroxide & Yes & Filtration efficiency and seal quality approved after 10 treatment cycles \\
\hline Low-temperature moist heat & No & Filtration efficiency and seal quality approved after 10 treatment cycles \\
\hline Ultraviolet germicidal irradiation & No & Filtration efficiency and seal quality approved after 10 treatment cycles \\
\hline Ethylene oxide & No & $\begin{array}{l}\text { Not recommended due to the risk of residual toxicity from ethylene } \\
\text { oxide (carcinogen) }\end{array}$ \\
\hline lonizing radiation & No & Not recommended because it may impair the performance of the filter \\
\hline Microwaves & No & $\begin{array}{l}\text { Not recommended due to risk of respirator melting near metal } \\
\text { components, compromising the seal }\end{array}$ \\
\hline Moist heat at over $75^{\circ} \mathrm{C}$ & No & Not recommended because it may cause degradation of the filter \\
\hline Ethanol & No & Not recommended because it may impair the performance of the filter \\
\hline
\end{tabular}

*N95 respirators - National Institute for Occupational Safety and Health (NIOSH).

${ }^{* *}$ To date, Brazil has not passed any regulations on the use of methods for the decontamination of respirators. 
Several decontamination studies fail to evaluate the survival of other pathogens that may contaminate respirators and also fail to evaluate the effect of the decontamination processes on their fit, seal and filter performance. ${ }^{12}$ Also, the studies do not include respirators that have been exposed to aerosol-generating procedures, which limits the applicability of this practice to respirators used in dentistry.

In times of serious supply shortages, the adoption of strategies such as the extended use and reuse of respirators are alternatives that could be recommended for optimizing stocks. The decision as to whether to permit the extended use and reuse of respirators is the responsibility of infection control committees at the institutions in question in consultation with disease/infection control agencies and public health authorities.

Clinical studies on the extended use and reuse of respirators are subject to ethical restrictions, since its recommendation is limited to exceptional situations of a limited duration during periods of crisis. In dental care, extended use, always in combination with a barrier (face shield) to reduce contamination of the respirator surface, is preferable to reuse.

\section{References}

1. CDC. Strategies for Optimizing the Supply of N95 Respirators. [acesso em 3 mai 2020]. Disponível em: https://www.cdc.gov/coronavirus/2019-ncov/hcp/ respirators-strategy/index.html

2. CDC. Recommended Guidance for Extended Use and Limited Reuse of N95 Filtering Facepiece Respirators in Healthcare Settings. [acesso em 3 mai 2020]. Disponível em: https://www.cdc.gov/niosh/topics/hcwcontrols/ recommendedguidanceextuse.html

3. ECRI. Clinical Evidence Assessment. Safety of Extended Use and Reuse of N95 Respirators. [acesso em 12 mai 2020]. Disponível em: https://www. elsevier.com/__data/assets/pdf_file/0006/997863/COVID-ECRI-N95Respirators_2020-03.pdf

4. Brady T M, Strauch A L, Almaguer C M, Niezgoda G, Saffer R E, Yorio P $\mathrm{L}$, et al. Transfer of bacteriophage MS2 and fluorescein from N95 filtering facepiece respirators to hands: Measuring fomite potential. J Occup Environ Hyg. 2017;14(11):898-906

5. ANVISA. NOTA TÉCNICA No 04/2020. Orientações para serviços de saúde: medidas de prevenção e controle que devem ser adotadas durante a assistência aos casos suspeitos ou confirmados de infecção pelo novo coronavírus (SARS-COV-2). (Atualizada em 8/05/2020). [acesso em 21 mai 2020]. Disponível em: http://portal.anvisa.gov.br/documents/33852/271858/ Nota+T\%C3\%A9cnica+n+04-2020+GVIMS-GGTES-ANVISA/ab598660 3de4-4f14-8e6f-b9341c196b28

6. 3M. Boletim técnico. Reuso de respiradores descartáveis. [acesso em 15 mai

2020]. Disponível em: https://multimedia.3m.com/mws/media/1825756O/ reuso-respiradores-descartaveis.pdf

7. CDC. Decontamination and Reuse of Filtering Facepiece Respirators. [acesso em 30 abr 2020]. Disponível em: https://www.cdc.gov/coronavirus/2019-ncov/ hcp/ppe-strategy/decontamination-reuse-respirators.html

8. Doremalen N V, Bushmaker T, Morris D H, Holbrook M G, Gamble A, Williamson B N, et al. Aerosol and surface stability of SARS-CoV-2 as compared with SARS-CoV-1. N Engl J Med. 2020; 382(16):1564-1567.

9. Coulliette A D, Perry K A, Edwards J R, Noble-Wang J A. Persistence of the 2009 pandemic influenza A (H1N1) virus on N95 respirators. Appl Environ Microbiol. 2013;79(7):2148-2155.

10.ANVISA.Perguntas erespostas. [acessoem 3 mai2020].Disponívelem:portal. anvisa.gov.br/documents/219201/4340788/Perguntas+e+Respostas+GGTES. pdf/7fce6e91-cf99-4ec2-9d20-1fb84b5a6c38

11. FDA. Emergency Use Authorizations. Personal Protective Equipment EUAs. [acesso em 17 mai 2020]. Disponível em: https://www.fda.gov/ medical-devices/emergency-situations-medical-devices/emergency-useauthorizations\#covid19ppe

12. 3M. Technical Bulletin. Decontamination Methods for $3 \mathrm{M}$ Filtering Facepiece Respirators such as N95 Respirators. [acesso em 14 mai 2020]. Disponível em: https://multimedia. $3 \mathrm{~m} . \mathrm{com} / \mathrm{mws} / \mathrm{media} / 18248690 /$ decontamination-methods-for-3m-filtering-facepiece-respirators-technicalbulletin.pdf

\section{Mini Curriculum and Author's Contribution}

1. Vanessa Paiva Reis - DDS. Contribution: Literature review, preparation, writing, and review of the manuscript. ORCID: 0000-0001-7682-547X

Submitted: 06/08/2020 / Accepted for publication: 06/10/2020

Corresponding author:

Vanessa de Paiva Reis

E-mail: vanepreis1@gmail.com 